\title{
THE ROLE OF POLYPLOIDY IN THE ADAPTIVE SIGNIFICANCE OF POLYMORPHISM AT THE GOT 1 LOCUS IN THE DACTYLIS GLOMERATA COMPLEX
}

\author{
R. LUMARET \\ Laboratoire de Génétique Ecologique, CEPE/CNRS Route de Mende, BP 5051, \\ 34033 Montpellier Cedex, France
}

Received 28.i.83

\section{SUMMARY}

Clinal variation along both altitudinal and latitudinal gradients was clearly observed in glutamate oxaloacetate transaminase gene frequencies (GOT 1 locus) from 21 diploid and 90 tetraploid populations of Dactylis glomerata $\mathbf{L}$. collected over the entire area of the primary and secondary geographic distribution of the species. This was the starting point for experiments designed to detect selective effects and determine the significance of polymorphism at this locus. Progressive investigations were made combining different approaches to determine correlations between allelic frequencies and environmental variables. Consistency of these correlations was tested by small scale studies in sites that exhibited gradients in particular environmental variables and comparisons of the in vitro activity of the allozymes were also made.

The results show that alleles, specifically three among the eight investigated, are not randomly distributed. Two of the alleles are correlated with humidity and the other allele with temperature.

From these experimental results and the data from natural populations, there appears to be an advantage to those individuals of this perennial species that possess maximal allelic diversity at this locus, especially in transitional climatic areas where variations in temperature and water availability are particularly high and unpredictable.

As only tetraploid plants with the highest allelic diversity are found in such fluctuating conditions, it is suggested that tetraploid genetic structure may be directly responsible for the wider niches of tetraploids than of diploids. Consequently, tetraploids may occupy a wider range of habitats and possess a stronger colonisation potential and wider spatial distribution than diploids.

\section{INTRODUCTION}

The intuitive notion that there are correlations between genetic variability and the ecological amplitude of populations is supported by results from several studies of polymorphism in animal and plant species (Maynard Smith, 1962; Clegg and Allard, 1972; Koehn and Mitton, 1972; Babbel and Selander, 1974; Gottlieb, 1975; Allard et al., 1978) including polyploid complexes (Roose and Gottlieb, 1976; Hancock and Bringhurst, 1979, 1981). In the latter cases, polyploids were generally found to have a higher genetic diversity and to be distributed over a wider range of habitats than their diploid progenitors but the selective mechanisms underlying this difference are not clear. One of the reasons for this lack of understanding may be the absence of data correlating genetic diversity with selective factors. Although patterns of genetic diversity including enzymatic polymorphism have often been shown to be non-random (Hamrick and Allard, 1972; Levy and Levin, 1975; Nevo and Bar, 1976; Levin, 1977; Bergmann, 1978; 
Valizadeh and Valdeyron, 1979; Nevo et al., 1979; Kahler et al., 1980; Anderson, 1981; Nevo and Yang, 1982), there have been very few cases where selective factors have been identified. When they have been, there are only a few situations where selection could be reasonably considered to act directly upon the alleles segregating at a specific locus. The best example concerns a haemoglobin polymorphism in man (Allison, 1955), other examples include enzymatic polymorphism as glucose-6-phosphatedehydrogenase in man (Luzzato et al., 1969) and alcohol dehydrogenase in Drosophila melanogaster (Clarke, 1975).

This paper is an attempt to determine the ecological significance of polymorphism at the GOT 1 locus which codes for glutamate oxalo-acetate transaminase allozymes in the naturally occurring polyploid complex, Dactylis glomerata. Since tetraploids originate from diploids in this species by autopolyploidy, several levels of genetic structural complexity and potential diversity at this locus can be considered and a direct comparison made between related groups of plants. Diploids are located in very specialised habitats while tetraploids are widely distributed in many variable environments. This situation provides a good opportunity to study the relationships between genetic variability and the ecological amplitude of populations in this allogamous species.

\section{MAterials AND MEthods}

21 populations of diploid plants from 13 out of the 14 subspecies of the primary geographical distribution of the species were studied (fig. 1). Most of this material came from the collections of M. Borril (Welsh Plant Breeding Station, Aberystwyth).

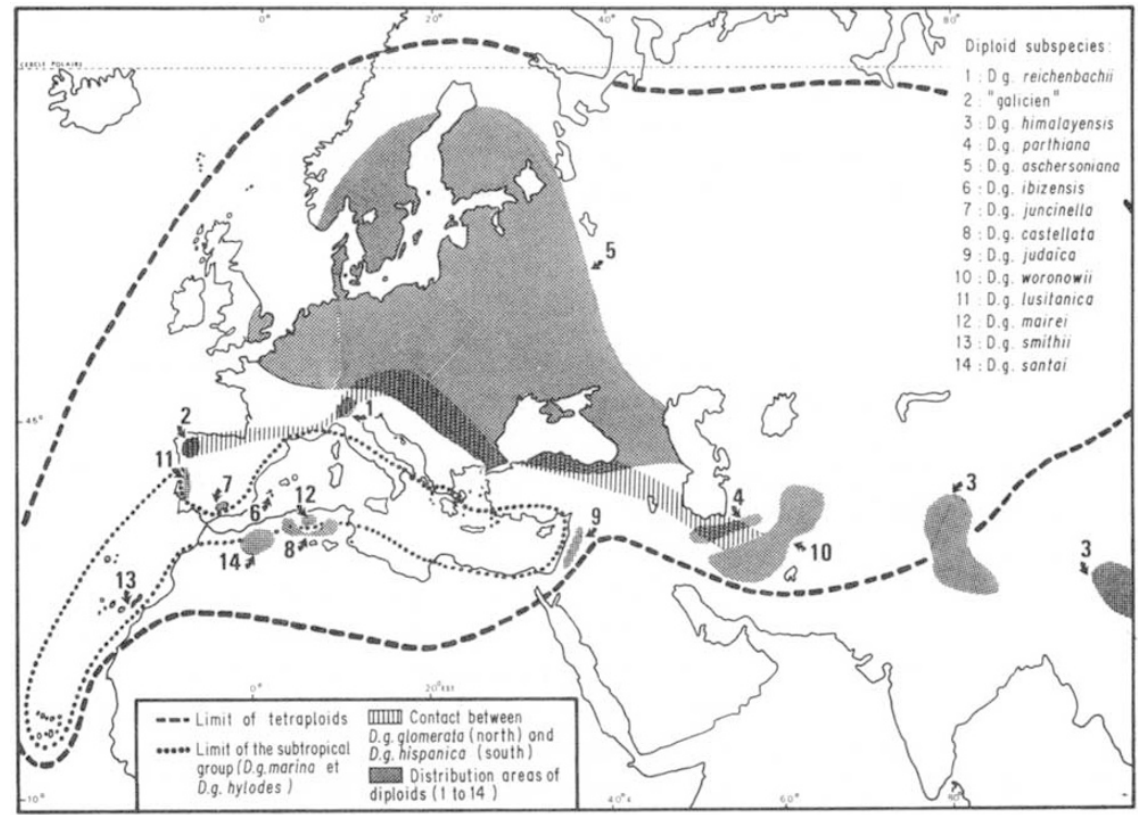

FIG. 1. The primary distribution of Dactylis. 
The tetraploid material had been derived from numerous locations in Europe and North Africa and from several additional sites in the secondary geographical distribution of the species: Vancouver (Canada; site 83), Azul and Necochea (Argentina; sites 84 and 85), Hill Road and Queenstown (New Zealand; sites 86 and 87 ). 90 populations were studied in total. They belong to the three tetraploid subspecies, D.g. glomerata (a mesic subspecies) D.g. hispanica (a mediterranean subspecies) and D.g. marina (a sub-tropical subspecies), or they were obtained from hybridisation areas between them. Gene flow is considered to be high between tetraploids but to be less frequent between diploids or heteroploids (Borrill, 1977).

This large-scale sampling was conducted according to latitude and altitude gradients. The geographical co-ordinate and altitude of collection sites were obtained from the Times Atlas of the World (The Times, London, 1967) and climatic data for adjacent weather stations from World Weather (Her Majesty's Stationery Office; London, 1967) and KlimadiagrammWeltatlas Jena (Walter and Lieth, 1967). Nine climatic variables were used.

Generally, twenty year averages were considered for each of the variables, and classes were determined and coded from the lowest to the highest values: annual rainfall ( 5 classes), average annual temperature in ${ }^{\circ} \mathrm{C}$ (4 classes), average daily minimum temperature for the coldest calendar month ( 3 classes), average daily maximum for the hottest calendar month (6 classes), number of months with minimum absolute temperature under $0^{\circ} \mathrm{C}$ ( 4 classes), number of months with average monthly temperature under $0^{\circ} \mathrm{C}$ ( 4 classes), number of months with aridity ( 4 classes) and intensity of aridity ( 5 classes) according to Gaussen's diagrams (1955) and the bioclimatic index of Giacobbe $(1959,1964)$ calculated from June to August in the northern hemisphere and from December to February in the southern hemisphere. For this last variable four classes ranging from mesic to the more arid climates (classes 1 to 4 ) were considered.

In addition, a small scale sampling was performed along two transects exhibiting clinal variation for soil water availability. The first, $40 \mathrm{~m}$ in length, is located in Southern France, at St Martin de Londres, near Montpellier, within a "garrigues" vegetation (Mediterranean shrub associations on limestone) containing the tetraploid Mediterranean subsp. hispanica; the second, $130 \mathrm{~m}$ long, is a sandy dune in Northumberland where the tetraploid glomerata subspecies is present. Characteristics of this site have been described in detail by Ashenden et al., (1975).

The inheritance of allozymes coded by the GOT 1 locus and the electrophoretic techniques used to detect them have been reported in a previous paper (Lumaret and Valdeyron, 1978). Allozyme assays were performed on leaf tissue, from plants in situ in the case of the small scale Mediterranean sampling, and in all other cases from seedlings grown from seeds collected in nature. The seeds were germinated and seedlings grown in the greenhouse for approximately 12 weeks until they were assayed. In general, one seedling individual was examined from each mother plant. The average number of plants per sample was 46 with a variance of $21.02 ; 82$ and 220 individuals respectively were analysed in the English and French transects.

Allelic expression was estimated for different pairs of alleles by the relative intensity of electrophoretic bands measured with a densitometer. Results were compared at $5^{\circ} \mathrm{C}$ and $38^{\circ} \mathrm{C}$ which were considered to be close 
to the two extreme temperatures under which plants may be found still growing in natural conditions. After the electrophoretic process, two pieces of the same gel containing extracts from the same plants were simultaneously used for staining bands at each of the two temperatures, other experimental conditions remaining identical.

\section{REsults}

(i) Geographic distribution of alleles

Allelic frequencies at the GOT 1 locus are shown in figs. 2 and 3 respectively for 21 diploid and 52 tetraploid populations. Eight alleles were found in the complex. One of them (GOT $\left.1^{0.90}\right)$ is only present in populations of several diploid subspecies; four $\left(G O T 1^{0.10}, G O T 1^{1 \cdot 26}, G O T 1^{1 \cdot 18}\right.$ and $G O T 1^{1.50}$ ) are characteristic of tetraploid populations. GOT $1^{0.10}$ is widely distributed in the sub-humid Mediterranean cool-summer regions. GOT $1^{1 \cdot 26}$ is usually found only in very low frequencies (less than 5 per cent) in the mesic climatic regions. GOT $1^{1.18}$ and GOT $1^{1.50}$ are very localised alleles: GOT $1^{1 \cdot 18}$ was only found in a population from Czechoslovakia and GOT $1^{1 \cdot 50}$ is a characteristic of the two Argentinian populations, $250 \mathrm{~km}$ apart (not represented in fig. 3). Three alleles are found in both diploid and tetraploid plants; GOT $1^{0.38}$ is principally present in the Mediterranean area; GOT $1^{1.00}$ and GOT $1^{0.72}$ are more widely distributed. Fig. 3 shows clearly that GOT $1^{1.00}$ is predominant in the north western region of Europe and its frequency decreases regularly southward, whereas the frequency of $G O T 1^{0.72}$, which is very high in the Mediterranean area, declines in the opposite direction. For these two alleles, the general pattern

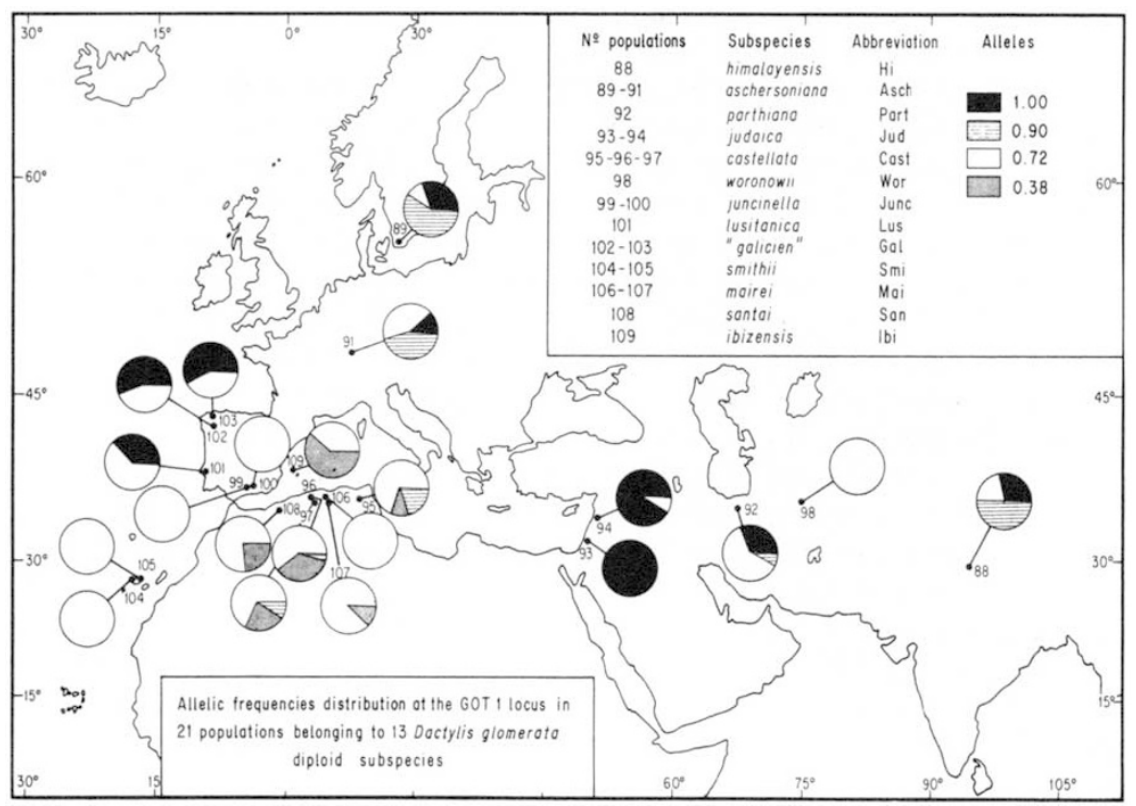

FIG. 2. Allelic frequencies distribution at the GOT 1 locus in 21 populations belonging to 13 Dactylis glomerata diploid subspecies. 


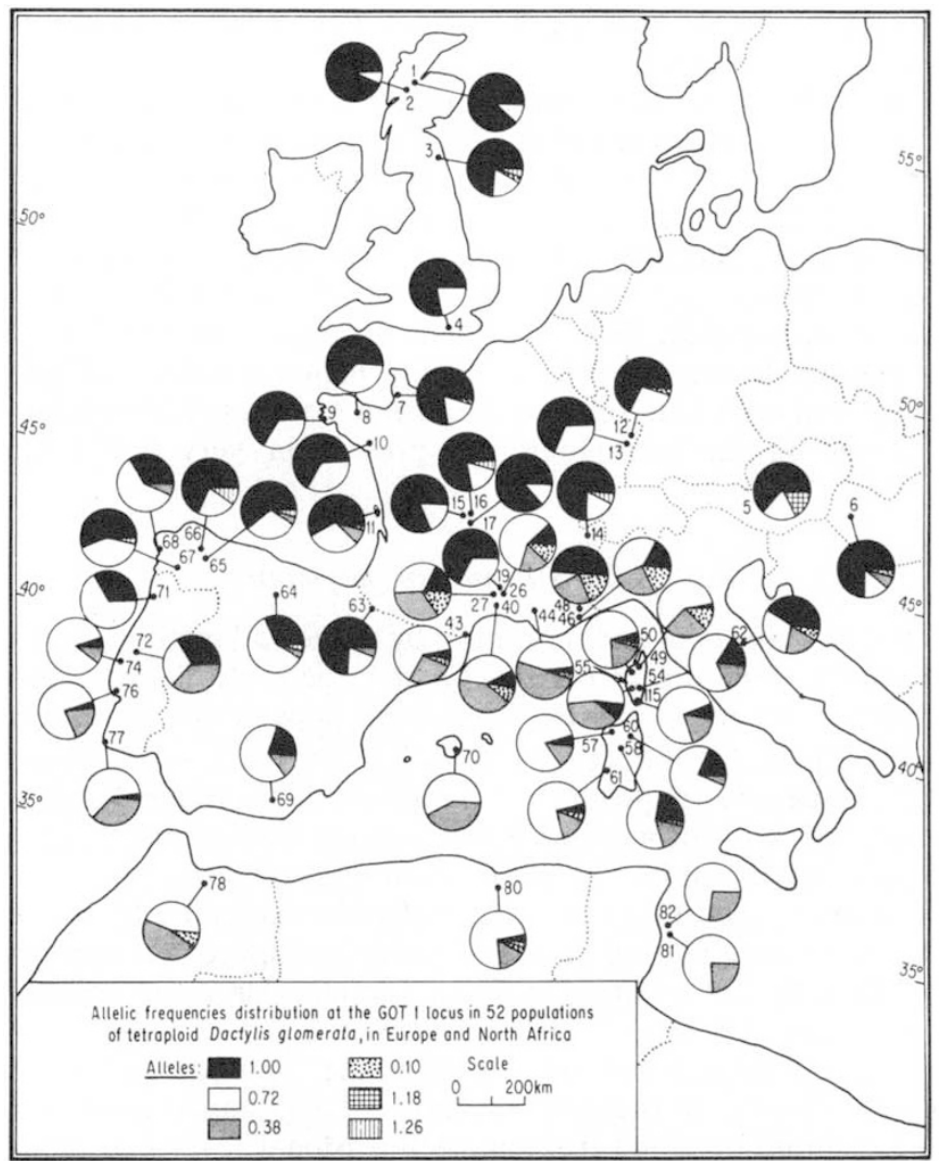

FIG. 3. Allelic frequencies distribution at the GOT 1 locus in 52 populations of tetraploids Dactylis glomerata, in Europe and North Africa.

of distribution in diploids (fig. 2) is similar to that found in tetraploids, since GOT $1^{0.72}$ frequencies are very high in the Mediterranean area and the GOT $1^{1.00}$ allele is mainly present in more mesic climatic regions with higher latitudes or altitudes. However, two exceptions were noticed. These are the two populations from Israel and Lebanon (subsp. judaica) which are classified in the Mediterranean group (Borrill, 1977) according to morphological traits. A general survey of polymorphism at 11 other loci coding for various systems confirmed the existence of high similarity between judaica and other subspecies growing under more mesic climates (Lumaret, 1981). This situation is a good illustration of the high discordance between morphological and biochemical characters which may be found in the evolutionary process.

The allelic diversity of diploid and tetraploid populations was also compared using the entropy measure of Shannon and Weaver (1963): $H_{\mathrm{pop}}=\sum_{i=1}^{i=n}-p_{i} \log _{2} p_{i}$, where $p_{i}$ is the frequency of the $i$ th allele and $n$ is the total number of alleles. This index combines diversity from both the numbers and frequencies of the alleles. 
For each $n$, the $H$ value is a maximum if the alleles are equi-frequent. In this case, $H_{\max }=\log _{2} n$.

$E=H_{\text {obs }} / H_{\max }$, called "equitability", reflects that part of the diversity due to frequency differences of alleles. This second index ranges from 0 to 1 and was also used in the analyses. The allelic diversity indices ranged from 0.32 to 1.95 in the 90 tetraploid populations studied in total (the average was 1.21 ) and between 0.00 to 1.49 in the diploid populations (the average was 0.69 ). Mean equitability was 0.86 and 0.74 respectively in diploids and tetraploids. This means that the higher diversity values found in the tetraploids are due mainly to the higher numbers of alleles per population and not to the relative proportions of these alleles (many of the alleles found in the tetraploids are present in very low frequencies; see fig. 3 ).

\section{(ii) Global structure of polymorphism}

Synthetic analyses of polymorphism by numerical methods were carried out to complement the direct survey of large scale geographical allelic distributions. Genetic distances, $d$, between populations were determined from their allelic distributions by: $d=\sqrt{\sum_{i=1}^{i=n}\left(1 / p_{i}\right)\left(x_{i}-y_{i}\right)^{2}}$, where $x_{i}$ and $y_{i}$ are the respective frequencies of the $i$ th allele (between 1 and $n$ ) in the two compared populations, and $p_{i}$ the average frequency of each allele in all the populations, and is the square root of a weighted $\chi^{2}$.

The respective positions of the populations estimated by the distances between them were plotted in multidimensional space and then projected upon a plane by non-metric multidimensional scaling (or proximity analysis) (Escoufier, 1975).

The same distances were also used as the basis for a cluster analysis (UPGMA). Clusters at the different levels of agglomeration were mapped onto the diagram obtained from multidimensional scaling so that concordance between the results from the two methods could be easily compared.

Global polymorphism at locus GOT 1 is indicated in fig. 4. The first two axes account for 59 per cent of the total variation. Five clusters were formed at level 15 of the hierarchical clustering (total scale ranging between 0 and 100). Clusters $I$ and $V$ are both characterised by presence of the GOT $1^{0.90}$ allele but they differ from each other because of the identity of the other alleles (GOT $1^{1.00}$ for I and GOT $1^{0.38}$ for V) that were present in the same populations. Cluster IV groups populations with the GOT $1^{0.38}$ allele. The two last clusters (II and III) include diploid or tetraploid populations aligned along axis 2 according to their frequencies for alleles $G O T$ $1^{1 \cdot 00}$ and GOT $1^{0.72}$ : as the values decrease along axis 2 , the frequency of the allele GOT $1^{1 \cdot 00}$ increases and that of allele GOT $1^{0.72}$ decreases.

The agreement between these two opposite gradients and geographical clines observed for the same two alleles (fig. 3) might be interpreted as a result of founder effects followed by gradual reciprocal introgressions. However a more detailed survey of gradients in fig. 4 shows numerous examples where populations (e.g., 8 and 67) that are geographically quite distant from each other, have very similar climatic conditions and are very close on the diagram. Furthermore, geographically very close populations (for example 25 and 26 only 30 meters apart) that have different microclimatic conditions are located in different clusters. These situations suggest 


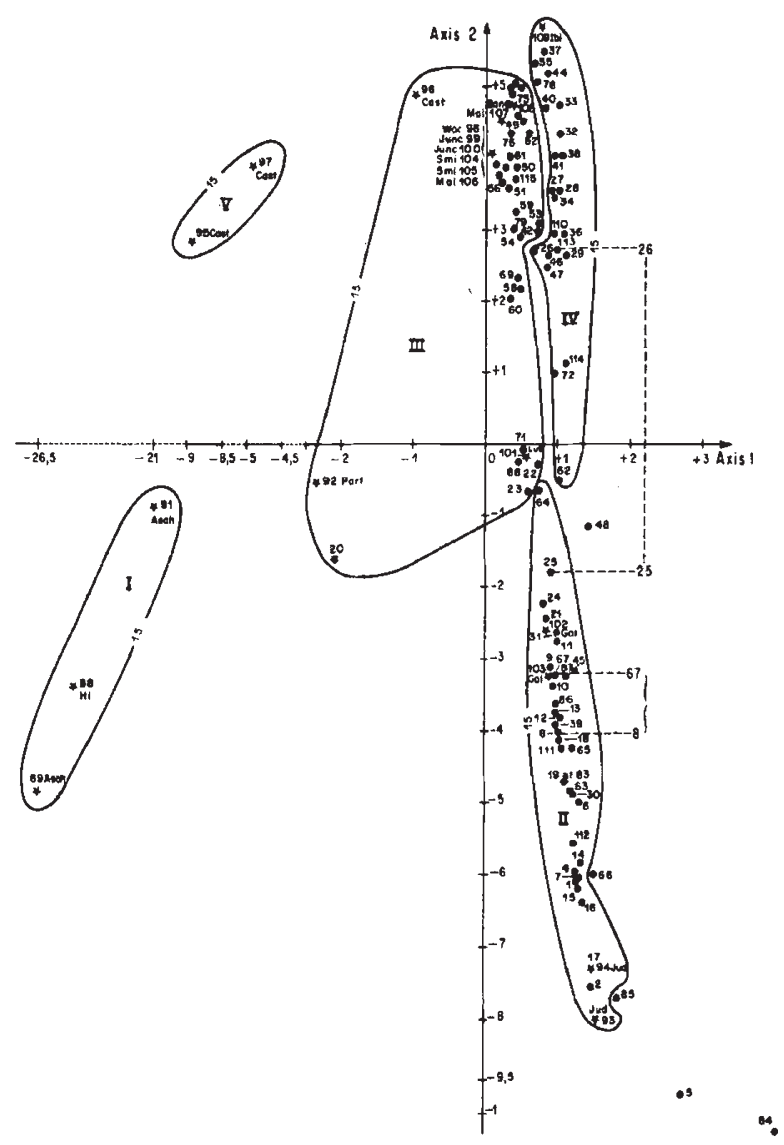

Fig. 4. Global structure of polymorphism at the GOT 1 locus in 21 diploid ( $\star$ ) and 90 tetraploid (๑) populations.

that local selection might have occured and this possibility was therefore considered in more detail.

(iii) Correlations between allelic frequencies and environmental variables

A correspondence analysis adapted from Benzecri (1973) was carried out to study relations between polymorphism at the GOT 1 locus and climatic variables at the collecting sites. This method is well suited to the data which were in the form of both frequencies of alleles and binary data for the different classes of each climatic variable. $\chi^{2}$ distances were calculated from the [allele-population] matrix and the respective positions of alleles were projected upon a plane defined by axes 1 and 3 which account respectively for 40.3 and 17.5 per cent of the total variation. A second matrix containing classes of the different climatic factors which were considered as additional variables was independently projected on the same plane. Relationships between alleles and the classes of the different climatic factors are established from the respective positions of these two types of variables. Results are shown in fig. 5. 


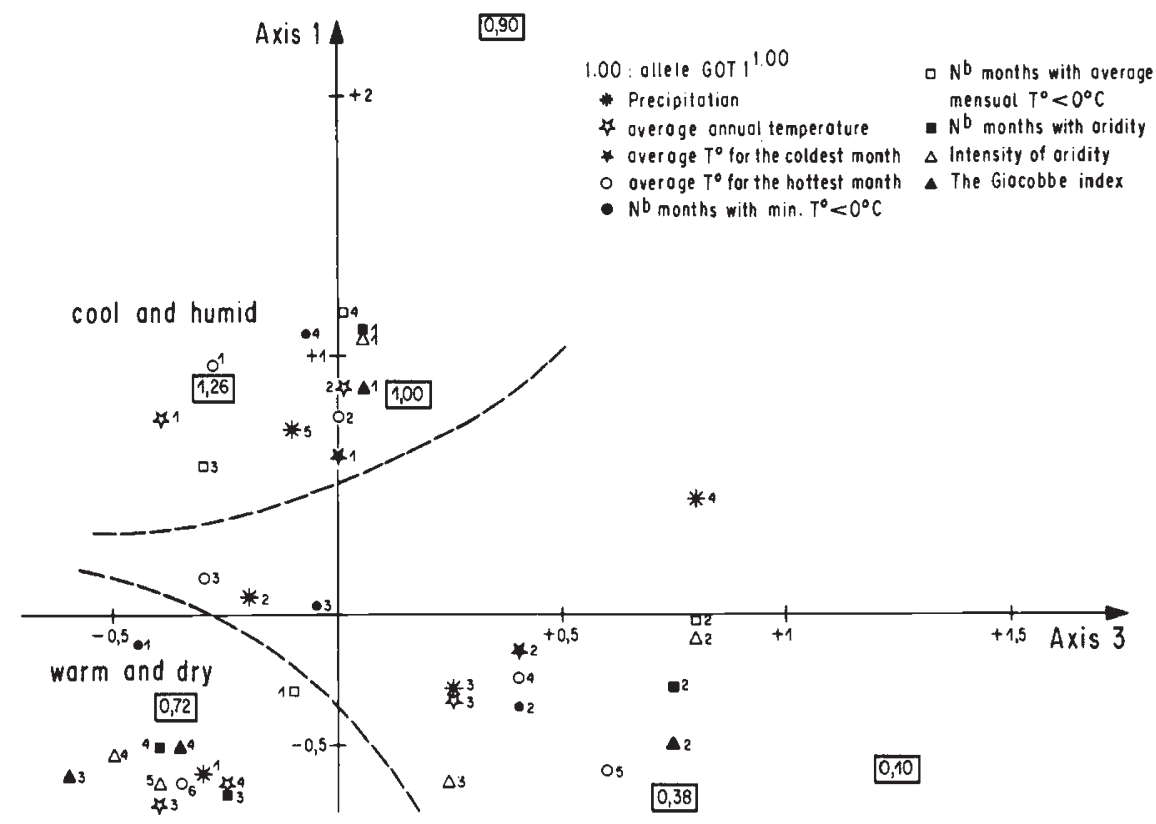

FIG. 5. Correspondence analysis between 6 alleles at the GOT 1 locus and climatic variables in 95 sites. Axis $1: 40 \cdot 3$ per cent variation. Axis $3: 17 \cdot 5$ per cent variation.

Symbols indicating the climatic variables are given in the figure with small numbers coding for classes (see explanation of this code in "Materials and Methods"). It can be observed, for example, that allele GOT $1^{1 \cdot 26}$ is very close to the white circle coded with 1 which represents the first class (lowest values) of the average temperature for the hottest month.

Alleles GOT $1^{1.26}$ and more particularly GOT $1^{1.00}$ are associated with characteristics of cool and humid climates. On the other hand the GOT $1^{0.72}$ allele is found in another distinct part of the diagram where variable values correspond to warm and arid climates.

The Giacobbe index value (less than 8 ) and length of aestival aridity (more than 4 months) which are generally considered to be good criteria for characterising xeric climates are the closest to the GOT $1^{0 \cdot 72}$ allele.

No clear rela'ionships were detected between the distribution of alleles $G O T 1^{0.38}, G O T 1^{0.10}, G O T 1^{0.90}$ and climatic variables but the rarity of the last two alleles may be sufficient to explain this.

Similar analyses were carried out with edaphic variables and several characteristics of the vegetation structure. It was clear from the results that no consistent correlations between allelic distributions at the GOT 1 locus and variation of these factors could be extracted.

\section{(iv) Directional variations of polymorphism}

The consistency of correlations between alleles and climatic factors was tested by small scale analyses of polymorphism at the GOT 1 locus along two transects exhibiting clinal variations in the availability of soil water. 
The Mediterranean transect (fig. 6) was divided into three parts (dry, intermediate and wet) according to the variation in specific composition using Haming's relative distance method (Gauthier and Godron, 1976). Roy (1980) has shown that plants from the driest and wettest parts of the transect differ in physiological responses to drought.

Polymorphism was examined for the three sub-populations in which four alleles were found in total. The allelic frequencies of two alleles, GOT $1^{1.00}$ and GOT $1^{0.72}$, were similar to the driest and intermediate parts where the soil was stony (from 15 to 30 per cent stones) and less than $50 \mathrm{~cm}$ deep while in the wettest part where the soil was much deeper $(1.20 \mathrm{~m}$ in the average) with only 2 per cent stones, the frequency of GOT $1^{1.00}$ increased while that of GOT $1^{0.72}$ decreased. The differences between the extreme parts of the transect were found to be significant at the 5 per cent level, using a chi-square test. In contrast, the frequencies of GOT $1^{0.38}$ and $G O T 1^{0.10}$ did not change significantly along the transect.

The same type of variation was observed for alleles GOT $1^{1.00}$ and GOT $1^{0.72}$ between populations from sites 1 and 6 of the English transect (fig. 7). Differences are significant at the 5 per cent level. As shown by drainage experiments, sites 1 and 6 were the wettest and the driest respectively along a strong gradient of soil water retention.

According to Ashenden et al. (1975), the population of $D$. glomerata at site 1 could have been derived from seed from hay brought in as forage for cattle annually since 1946 . The plants are thought then to have spread to the top of the dune (site 6) by animal or wind transport. Ashenden (1978) found that plants from seeds collected in site 6 exhibited morphological features as well as physiological characteristics associated with drought avoidance. These characteristics were not present in plants from site 1 .

In addition, 20 and 21 individuals, were analysed from sites 2 and 4 respectively. Water retention characteristics of site 2 were very similar to those of site 1 (the wettest site) and site 4 was considered by Ashenden (1978) as a dry site very similar to site 6 (the driest site). The GOT $1^{1 \cdot 00}$ and GOT $1^{0.72}$ frequencies were found to be respectively 0.75 and 0.24 at site 2, 0.70 and 0.30 at site 4 . Although analysis of many more individuals would be necessary to detect significant differences, the results are consistent with the general pattern of variation.

The contrasting variation in the frequencies of GOT $1^{1.00}$ and GOT $1^{0.72}$ was found in numerous other situations in which polymorphism at the GOT 1 locus was compared for paired groups of plants from nearby sites which differed principally in soil moisture status. Examples are given in table 1 for three localities near Montpellier (South of France). In every case, the results were consistent with those obtained previously from the transect studies.

(v) Comparison of the relative expression of alleles in vitro with temperature.

The allelic expression of GOT $1^{1.00}$, GOT $1^{0.72}$, GOT $1^{0.38}$ and GOT $1^{0.10}$ was measured by densitometry from band intensity on zymograms and compared at $5^{\circ} \mathrm{C}$ and $38^{\circ} \mathrm{C}$. Heterozygote diploid or digenic duplex tetraploid genotypes were used for this purpose by combining each of these four alleles in pairs. 


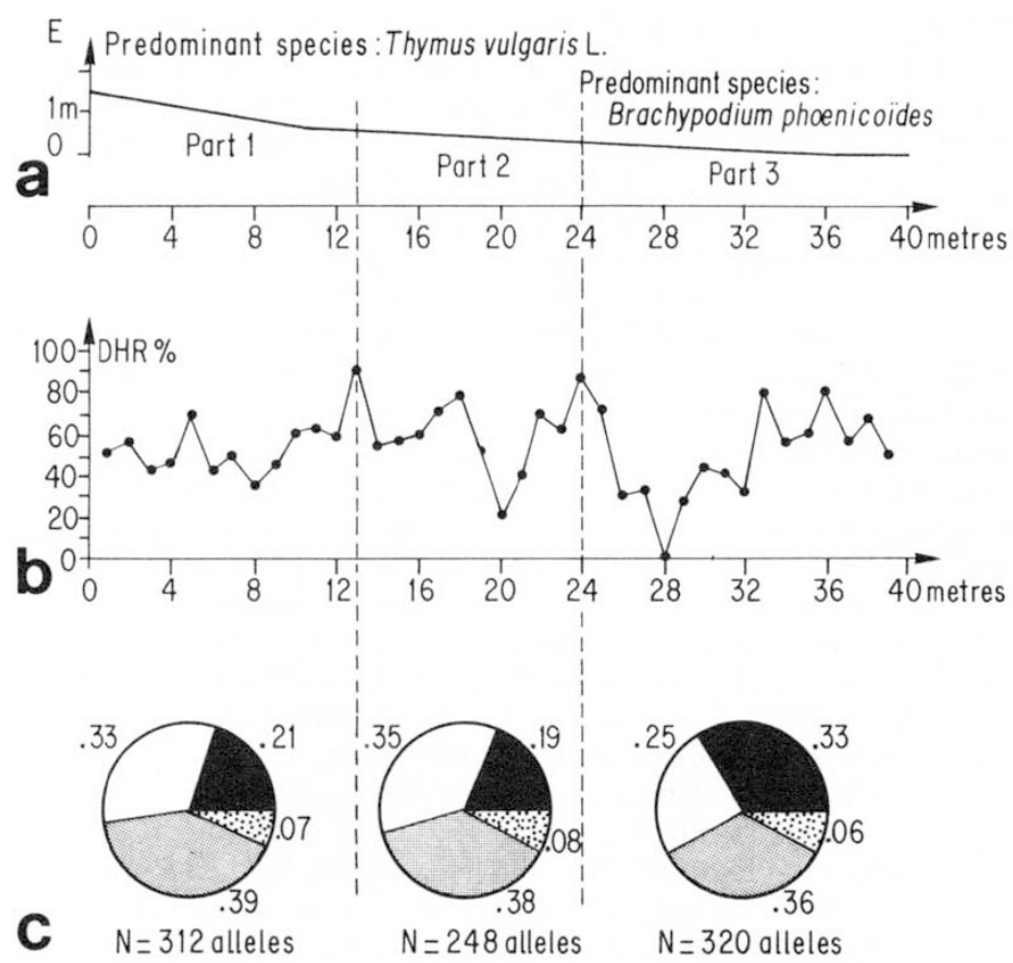

Alleles at the GOT 1 locus

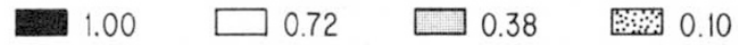

FIG. 6. The Mediterranean transect: (a) Topographical profile; (b) Specific diversity of the vegetation (DHR are the relative distances of Haming); (c) Allelic frequencies at the GOT 1 locus in the three parts determined from the vegetation analysis (the arrow indicates the direction of water stress).

No consistent difference was noticed between alleles at either of the two temperatures except for genotypes including $G O T 1^{0 \cdot 10}$. At $38^{\circ} \mathrm{C}$, the expression of GOT $1^{0.10}$ is approximately half of that observed for each of the other three alleles, but at $5^{\circ} \mathrm{C}$ the intensity of this band is equal to that of GOT $1^{1.00}$ and GOT $1^{0.72}$ and a little stronger than that of GOT $1^{0.38}$ as can be seen from fig. 8. These results were repeated many times either with successive extracts from the same plants or with identical genotypes from different populations.

The frequency of GOT $1^{0 \cdot 10}$ in the field never exceeded 10 per cent in any population, except in 11 of the 41 tetraploid populations where the allele was present. Each of these 11 populations was located in upland Mediterranean areas characterised by aridity in summer, during which plants cannot grow, and by very low temperatures in winter. Plants of the Mediterranean subspecies (hispanica) usually grow in winter whereas those of the subspecies glomerata which occurs in cold temperate areas stop growing 


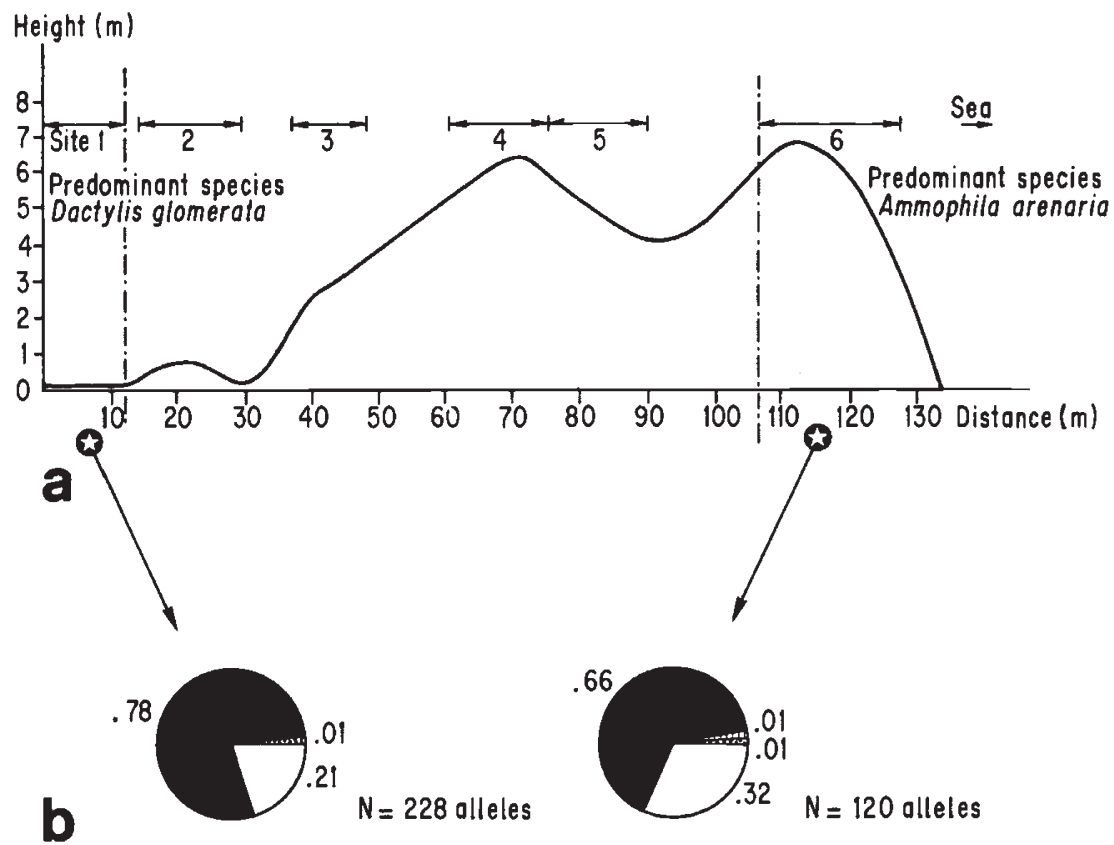

Alleles at the GOT I locus

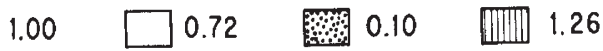

FIG. 7. The "Druridge bay" transect: (a) Topographical profile of the dune (according data of Ashenden et al., 1975); (b) Allelic frequencies at the GOT 1 locus in sites 1 and 6.

\section{TABLE 1}

Comparison of allelic distributions at the GOT 1 locus in three pairs of close localities near Montpellier (South of France). The first site is the driest and the second the wettest. Allelic frequencies are in parentheses

\begin{tabular}{ccccccccc}
\hline $\begin{array}{c}\text { No. } \\
\text { pop. }\end{array}$ & $\begin{array}{c}\text { Locality } \\
\text { and site }\end{array}$ & $\begin{array}{c}\mathrm{Nb} \\
\text { plants }\end{array}$ & GOT $1^{1.00}$ GOT $1^{0.72}$ & GOT $1^{0.38}$ & GOT $1^{0.10}$ & $\chi^{2}$ \\
\hline 26 & $\begin{array}{c}\text { Col de Mourèze } 1 \\
\text { (South face) }\end{array}$ & 39 & $28(18)$ & $90(58)$ & $22(14)$ & $16(10)$ & $33 \cdot 16$ \\
$\begin{array}{c}\text { Col de Mourèze } 2 \\
\text { (North face) }\end{array}$ & 29 & $57(49)$ & $49(42)$ & $06(05)$ & $04(04)$ & $* *$ \\
40 & $\begin{array}{c}\text { Aumelas 1 } \\
\text { (shallow soil) } \\
\text { Aumelas 2 } \\
\text { (deep soil) }\end{array}$ & 59 & $14(06)$ & $99(42)$ & $97(41)$ & $26(11)$ & $8 \cdot 72$ \\
41 & $26(14)$ & $64(34)$ & $79(42)$ & $19(10)$ & $*$ \\
28 & $\begin{array}{c}\text { Causse de la Selle 1 } \\
\text { (open habitat) }\end{array}$ & 36 & $20(14)$ & $58(40)$ & $50(35)$ & $16(11)$ & $11 \cdot 86$ \\
$\begin{array}{c}\text { Causse de la Selle 2 } \\
\text { (closed habitat) }\end{array}$ & 39 & $36(23)$ & $37(24)$ & $69(44)$ & $14(09)$ & $* *$ \\
\hline
\end{tabular}

Levels of significance: ${ }^{*}=P<0.05 ;{ }^{* *}=p<0.01$. 


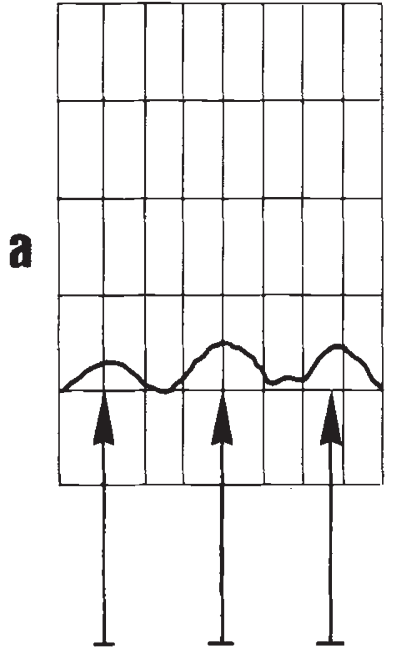

$(0.38 / 0.38)(0.38 / 0.10)(0.10 / 0.10)$

$$
5^{\circ} \mathrm{C}
$$

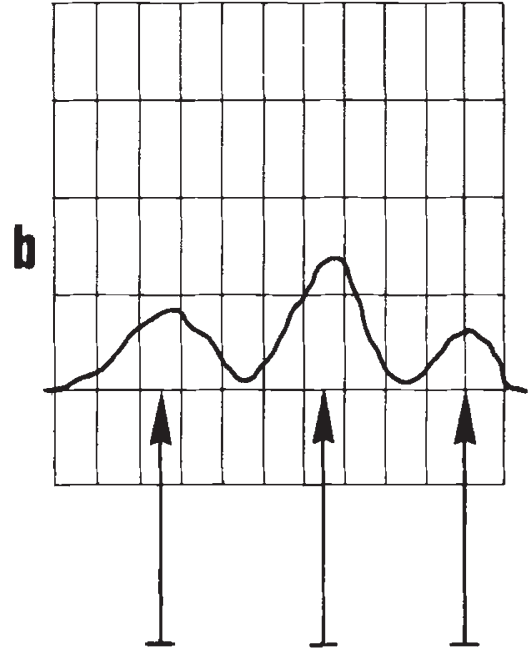

$(0.38 / 0.38)(0.38 / 0.10)(0.10 / 0.10)$

FIG. 8. Comparison of the in vitro relative expression of alleles GOT $1^{0.38}$ and GOT $1^{0 \cdot 10}$ with temperature: Densitometric registration of band intensity for both homodimers $(0 \cdot 38 / 0 \cdot 38,0 \cdot 10 / 0 \cdot 10)$ and the heterodimer $(0 \cdot 38 / 0 \cdot 10)$ at the GOT 1 locus.

from autumn to spring. Experimental studies made by Eagles and Ostgard (1971) concluded that at low temperatures $\left(5^{\circ} \mathrm{C}\right)$, the Norwegian populations of Dactylis showed reduced leaf expansion in contrast to the Portuguese which continued active leaf expansion. At $25^{\circ} \mathrm{C}$ the relative performance of the two groups was reversed. Activity of enzymes coded by the GOT 1 locus was found to be in direct relationships with leaf development (Lumaret, 1981).

In a few situations, direct contacts between natural populations of the two subspecies glomerata and hispanica occurred in the same locality, generally as a result of human activity. Such a situation was described from the Crau, the low Rhône region in South of France. In this region, native populations belong to the hispanica type and occupy the more xeric habitats. Plants of the glomerata type originating from the Alps were brought to the lowlands by water in rivers used for irrigation (Hugues et al., 1949). Their growth throughout the year is maintained in the wetter and cooler environments created by irrigation. In this situation, gene flow between populations of the two subspecies was detected. Though the GOT $1^{0.38}$ and GOT $1^{0 \cdot 10}$ alleles are absent from the original glomerata type and are present in the hispanica subspecies (with high frequency for GOT $1^{0.38}$ and low frequency for $\left.G O T 1^{0 \cdot 10}\right)$, they were both present in the irrigated populations of the Crau. In these populations the frequency of occurrence of GOT $1^{0 \cdot 10}$ was found to be higher than that of GOT $1^{0.38}$ (Lumaret and Valdeyron, 1980; Gouyon et al., in press).

There appears therefore to be a consistent relationship between the in vitro observed variability in the expression of GOT $1^{0 \cdot 10}$ with temperature 
and variation of frequencies of this allele in natural populations depending upon the different climatic conditions.

\section{Discussion}

The repeatability and the general consistency of results obtained from the different approaches and the studies using several levels of investigation support the idea that the allelic distributions and especially those of $G O T$ $1^{1.00}, G O T 1^{0.72}$ and GOT $1^{0.10}$ suggest the occurrence of selective effects. The nature of any selective forces remains to be precisely determined, but water availability and temperature seem to be the most probable. These two factors are often closely associated in the immediate environment of plants. They would act at a local level and variation on a wider scale could be considered as integrating that which occurs in the local sites.

However, as has already been reported (Clarke, 1975), even the most sophisticated genotype-environment correlations fail to show that selection is acting directly on the locus being observed and do not contradict a notion of neutrality. For example, selection might be acting on a locus tightly linked to the one whose product is studied. The linkage might be explained by chance, although the linkage groups themselves may be interpreted as the result of selection.

If the observed pattern of polymorphism distribution at the GOT 1 locus is interpreted as the direct result of selection, the selective values conferred on genotypes by the different alleles would appear to depend on environmental conditions, particularly water availability and temperature. With this interpretation, the effects of the different environmental conditions on allelic diversity can be estimated by classifying populations according to their respective environments described by these two types of climatic characteristic. This allows the level of diversity to be compared in the different situations. The test was run with data from the tetraploid populations. The average daily minimum temperature for the coldest calendar month ( 3 classes) and the bioclimatic index of Giacobbe for summer months ( 4 classes) were both chosen as variables. The number of populations scored in each of the twelve arrangements (classes I to XII) was put in parentheses in table 2 . This table gives in addition the average values of allelic diversity (Shannon's entropy index), at the GOT 1 locus for populations of each class.

It can be observed from the results that the enzymatic diversity is lowest either in classes I and II, which correspond to cold winters and cool wet summers, or in classes IX and XII with dry summers and winters without frost (generally winter is also the wettest season). Populations in situations I and II are summer growing while those in situations IX and XII are winter growing. In these four situations, climates may be oceanic or have continental tendencies on the one hand while being true Mediterranean climates, on the other hand. They were all found in addition to be stable and predictable and Dactylis populations were supposed to have narrow niches* in these conditions. All the diploid populations could be classified in these four classes.

The highest allelic diversities were obtained in classes IV and V where there is a possibility of both drought in summer and frost in winter. All

* niche: an $n$ dimensional space including all physiological requirements of a species (Hutchinson, 1958). 
TABLE 2

Average allelic diversity (measured by the Shannon entropy) at the GOT 1 locus according to aridity (estimated by the Giacobbe index) and to winter temperatures in tetraploid populations of Dactylis. $\mathrm{Nb}$ of populations are indicated in parenthesis; I: number of arrangements, *: indicates that diploids could be classified in these arrangements

\begin{tabular}{|c|c|c|c|}
\hline & \multicolumn{3}{|c|}{$\begin{array}{l}\text { Average daily minimum temperature for the coldest } \\
\text { month (in }{ }^{\circ} \mathrm{C} \text { ) }\end{array}$} \\
\hline & 4 & 4 to 8 & 8 \\
\hline \multicolumn{4}{|l|}{$\begin{array}{l}\text { Giaccobe } \\
\text { Index }\end{array}$} \\
\hline$>50$ & I & II & III \\
\hline \multirow{2}{*}{ humid } & 1.06 & 1.06 & 1.23 \\
\hline & $*(24)$ & $*(8)$ & (1) \\
\hline \multirow{3}{*}{$\begin{array}{l}20 \text { to } 50 \\
\text { sub-humid }\end{array}$} & IV & V & VI \\
\hline & 1.41 & $1 \cdot 72$ & $1 \cdot 14$ \\
\hline & (7) & (12) & (3) \\
\hline \multirow{3}{*}{$\begin{array}{l}8 \text { to } 20 \\
\text { semi-arid }\end{array}$} & VII & VIII & IX \\
\hline & $1 \cdot 18$ & 1.07 & 0.93 \\
\hline & (1) & $(5)$ & *(11) \\
\hline \multirow{3}{*}{$\begin{array}{c}<8 \\
\text { arid }\end{array}$} & $\mathbf{x}$ & XI & XII \\
\hline & - & - & 1.00 \\
\hline & & & $*(1)$ \\
\hline
\end{tabular}

populations in these two classes were found to be in the generally more mesic Mediterranean cool-summer regions and face the sub-humid Mediterranean climate principally characterised by a wider range of interannual variation and a high unpredictability (Mascart, 1925; Baudière and Emberger 1959; Saintignon and Martin, 1974; Thiebaut, 1979). Most of these populations belong to the Mediterranean subspecies and they usually grow from autumn to spring. There may be a partial or total lack of rain in spring and autumn (the two normal periods of precipitation) and long lasting winter frosts may occur in some years. These can produce important disturbances which may result in decrease or total absence of seed or leaf production over a period of one or two years but the plants can still survive. In these situations, a high allelic diversity can be considered as a genetic adaptation of these perennial plants (whose life-span is 10 years on average) to cope with these fluctuating conditions. No diploid populations were found in such situations.

Similar general genetic patterns have been described previously in animal or plant species. In most cases, the occurrence of selective effects was mentioned (Beardmore, 1970; Clegg and Allard, 1972; Babbel and Selander, 1974; Gillespie and Langley, 1974; Nevo and Bar; 1976, Miller, 1977), but high diversity was sometimes considered as being due to migration and reciprocal introgression between populations adapted to different environments (Soulé, 1971). In the case of Dactylis the consistency of this gene flow-variation interpretation is upset by the results from demographic studies carried out over a five year period, using tetraploid populations growing in unstable climatic conditions (Tomekpe et al., 1982 and Tomekpe, unpublished). The four alleles GOT $1^{1 \cdot 00}$, GOT $1^{0.72}, G O T 1^{0.38}$ 
and GOT $1^{0 \cdot 10}$ were present in all the populations of the region and both trigenic (individuals with three different alleles at the locus) and tetragenics (four alleles) occurred at between 27 and 60 per cent (averages, 47 per cent) of the total individuals. Evidence was obtained that plants which possess the highest level of heterozygosity (three or four alleles per locus) have statistically the greatest longevity and the highest annual production of seeds. This correlation was mainly observed with the GOT 1 locus and was considered in this case as an effect of overdominance. An example of such results is given in table 3; more extensive data will be published later (Tomekpe and Lumaret, in preparation). According to Johnson (1974), the biochemical interpretation of this result would be that, in the event of changed reaction conditions associated with varying environments, the possession of several allelic forms of the same enzyme may permit the tetraploid to maintain a sufficient flux through metabolic pathways.

TABLE 3

Average number of panicles per plant and average leaf weight per plant according to genotype at locus GOT 1 ( $M=$ monogenic; $S=$ simplex-digenic; $D=$ duplex-digenic $T R I=$ trigenic and $T E T=$ tetragenic) in the Dactylis population No. 27 from the south of France

\begin{tabular}{cccc}
\hline Genotype & $\begin{array}{c}\text { Number } \\
\text { of plants }\end{array}$ & $\begin{array}{c}\text { Average number of } \\
\text { panicles per plant }\end{array}$ & $\begin{array}{c}\text { Average leaf weight } \\
\text { per plant }\end{array}$ \\
\hline M & 46 & $17 \cdot 76$ & 0.95 \\
S & 161 & $19 \cdot 54$ & $1 \cdot 28$ \\
D & 124 & 20.99 & $1 \cdot 33$ \\
TRI & 116 & 23.81 & $1 \cdot 35$ \\
TET & 5 & 26.60 & $1 \cdot 54$ \\
\hline Significant & & M-TRI** & M-D** \\
differences & & S-TRI** & M-TRI** \\
& & D-TRI* & M-S* \\
& & M-TET* & \\
\hline
\end{tabular}

* Denotes significance at 5 per cent level; ** denotes significance at 1 per cent level (data from K. Tomekpe (pers. comm.)).

Finally, it appears to the present author that the most important conclusions supported by this study are (a) the high probability of adaptive significance of polymorphism at the GOT 1 locus in the Dactylis complex and (b) a wider range of genetic diversity with, consequently, a wider range of ability to adjust to environmental conditions, in tetraploids compared with diploids.

Taking the results together to make one general observation, we would postulate that differences in the genetic structure between diploid and tetraploid individuals could be directly responsible for differences in tolerance of total environmental experience, and therefore in the width of their respective niches. This could explain why polyploids are generally found to possess effectively a wider ecological distribution than their diploid progenitors. 
Acknowledgments. I am grateful to Dr M. Borrill from the Welsh Plant Breeding Station of Aberystwyth for giving seeds from numerous locations of diploids, counting the chromosomes and for his helpful comments and advice during the preparation of this paper.

Professor J. Harper and Dr C. Gliddon from the School of Botany (Bangor) provided useful comments on the manuscript.

\section{REFERENCES}

Allard, R. W., MILleR, R. D. AND KAHLER, A. L. 1978. The relationship between degree of environmental heterogeneity and genetic polymorphism. In Freysen, A. H. J. and Woldendorp, J. W. (eds.) Structure and Functioning of Plant Populations, North-Holland Publ., New York, pp. 49-73.

ALlison, A. C. 1955. Aspects of polymorphism in man. Gold Spring Harbor Symp. Quant. Biol., 20, 239-255.

ANDERSON, P. R. 1981. Geographic clines and climatic associations of Adh and Gpdh gene frequencies in Drosophila melanogaster. In Gibson, J. B. and Oakeshott, J. G. (eds.) Genetic Studies of Drosophila Populations, Australian National University, Canberra, pp. 237-250.

ASHENDEN, T. W. 1978. Drought avoidance in sand dune populations of Dactylis glomerata. J. Ecol., 66, 3, 943-951.

ASHENDEN, T. W., STEWART, W. S. AND WATKIN, W. 1975. Growth responses of sand dune populations of Dactylis glomerata L. to different levels of water stress. J. Ecol, 63, 97-107.

BABBEL, G. R. AND SELANDER, R. K. 1974. Genetic variability in edaphically restricted and widespread plant species. Evolution, 28, 619-630.

BAUDIERE, A. AND EMBERGER, L. 1959. Sur la notion de climat de transition en particulier dans le domaine du climat méditerraneen. Bull. Serv. Carte Phytogeogr., 4, 2, 95-117.

BEARDMORE, J. 1970. Ecological factors and the variability of gene-pools in Drosphila. In Hecht, M. K. and Steere, W. C. (eds). Essays in Evolution and Genetics in Honour of Theodosius Dobzhansky, Appleton Century Crofts, New York, pp. 299-314.

BENZECRI, J. P. 1973. L'analyse des données. II. L'analyse des correspondances. Dunod ed. Paris.

BERGMANN, F. 1978. The allelic distribution at an acid phosphatase locus in Norway spruce (Picea abies) along similar climatic gradients. Theor. Appl. Genet., 52, 2, 57-64.

BORRILL, M. 1977. Evolution and genetic resources in cocksfoot. Ann. Report of Welsh Plant Breeding Station, Aberystwyth, GB, 190-209.

CLARKE, B. 1975. The contribution of ecological genetics to evolutionary theory: detecting the direct effects of natural selection on particular polymorphic loci. Genetics, 79, 101-113.

CleGG, M. T. AND ALLARD, R. W. 1972. Patterns of genetic differentiation in the slender wild oat species Avena barbata. Proc. Natl. Acad. Sci., USA, 69(7), 1820-1824.

EAGLES, C. F. AND OSTGARD, O. 1971. Variation in growth and development in natural populations of Dactylis glomerata from Norway and Portugal. I Growth analysis. J. Appl. Ecol., 8, 367-382.

ESCOUfIER, Y. 1975. Le positionnement multidimensionel. Rev. Stat. Appl., 23(4), 5-14.

GAUSSEN, H. 1955. Expression des milieux par des formules écologiques. Leur représentation cartographique. Ann. Biol., 31, 257-269.

GAUTHIER, B. AND GODRON, M. 1976. La recherche de limites ou de coupures optimales; application à un relevé phytosociologique. Naturaliste Can., 103, 203-214.

GIACOBBE, A. 1959. Nouvelles recherches écologiques sur l'aridité dans les pays de la Méditerranée occidentale. Nat. Monsp., 11, 7-27.

GIACOBBE, A. 1964. La mesure du bioclimat méditerranéen. Nat. Monsp., 16, 43-67.

GILLESPIE, J. H. AND LANGLEY, C. H. 1974. A general model to account for enzyme variation in natural populations. Genetics, 76, 837-884.

GOTTLIEB, L. O. 1975. Allelic diversity in the outcrossing annual plant Stephanomeria exigua ssp. carotifera (Compositae). Evolution, 29, 213-225.

GOUYON, P. H., LUMARET, R., VALDEYRON, G. AND VERNET, PH. 1984. Reproductive strategies and disturbances by man. In Mooney et al., Disturbance and Ecosystems. Springer Verlag edit. (in Press).

HAMRICK, J. L. AND ALLARD, R. W. 1972. Microgeographical variation in allozyme frequencies in Avena barbata. Proc. Nat. Acad. Sci. USA, 69(8), 2100-2104.

HANCOCK, J. F. AND BRINGHURST, R. S. 1981. Evolution in California populations of diploid and octoploid Fragaria (Rosaceae): a comparison. Amer. J. Bot., 68(1), 1-5. 
HUGUES, P., MAYER, P. AND REBISCHUNG, J. 1949. Etude comparée de populations de Dactyle et de Fromental. C.R. Acad. Agri. Fr., 35, 510-519.

HUTCHINSON, G. E. 1958. Concluding remarks. Cold Spring Harbor Symp. quant. Biol., 22, 415-427.

JOHNSON, G. B. 1974. Enzyme polymorphism and metabolism. Science, 184, 28-37.

KAHLER, A. L., ALlARD, R. W., KRZAKOWA, M., WEHRAHN, C. F. AND NEVO, E. 1980. Associations between isozyme phenotypes and environment in the slender wild oat (Avena barbata) in Israel. Theor. Appl. Genet., 56, 31-47.

KOEHN, R. K. AND MITTON, J. B. 1972. Populations genetics of marine pelecypods. I. Ecological heterogeneity and evolutionary strategy at an enzyme locus. Am. Naturalist, 106, 47-56.

LEVIN, D. A. 1977. The organization of genetic variability in Phlox drummondii. Evolution, $31,477-481$.

LEVY, M. AND LEVIN, D. A. 1975. Genic heterozygosity and variation in permanent translocation heterozygotes of the Oenothera biennis complex. Genetics, 79, 493-512.

LUMARET, R. 1981. Structure génétique d'un complexe polyploïde: Dactylis glomerata $L$ Relation entre le polymorphisme enzymatique et certains aspects de la biologie, de l'écologie et de l'évolution de l'espèce. Thèse Doct. Etat, Univ. Sci. Tech. Languedoc, Montpellier (France), pp. 1-168, annexes I-V.

LUMARET, R. AND VALDEYRON, G. 1978. Les glutamate oxaloacétate transaminases du Dactyle (Dactylis glomerata L.): génétique formelle d'un locus. C.R. Acad. Sci. Paris, 287, $D, 705-708$.

LUMARET, R. AND VALDEYRON, G. 1980. Les dactyles de la Crau: mise en évidence de relations entre les différents écotypes par le polymorphisme enzymatique. C.R. Acad. Agric. Fr., 229-238.

LUZZATO, L., USANGA, E. A. AND REDDY, S. 1969. Glucose-6-phosphate dehydrogenase deficient red cells: resistance to infection by malarial parasites. Science, 164, 839-844.

MASCART, J. 1925. Notes sur la variabilité des climats I: Introduction generale historique. Audin Ed. 302 p.

MAYNARD SMITH, J. 1962. Genetic polymorphism in a varied environment. Am. Naturalist, $104,487-490$.

MILlER, R. D. 1977. Genetic Variability in the Slender Wild Oat Avena barbata in California. Ph.D. Thesis, University of California, Davis.

NEVO, E. AND BAR, Z. 1976. Natural selection of genetic polymorphism along climatic gradients. In Karlin, S. and Nevo, E. (eds.), Population Genetics and Ecology, Academic Press, Inc., New York, San Francisco, London, pp. 159-182.

NEVO, E., BROWN, A. H. D. AND ZOHARY, D. 1979. Genetic diversity in the wild progenitor of barley in Israel. Experimentia, 35, 1027-1029.

NEVO, E. AND YANG, S. Y. 1982. Genetic diversity and ecological relationships of Marsh frog populations in Israel. Theor. Appl. Genet., 63, 317-330.

ROOSE, M. L. AND GOTTLIEB, L. D. 1976. Genetic and biochemical consequences of polyploidy in Tragopogon. Evolution, 30, 818-830.

ROY, J., 1980. Comportement photosynthétique et hydrique de la feuille chez Dactylis, glomerata L. Adaptation phénotypique et génotypique à la sècheresse. Thèse Doct. 3ème cycle, Ecol. Gén. Appl., Univ. Sci. Tech. Languedoc, Montpellier (France).

SAINTIGNON, M. F. AND MARTIN, S. 1974. Application de l'analyse factorielle en composantes principales à l'étude de la variabilité régionale et interannuelle des précipitations ardéchoises. Rev. geogr. Lyon. 49, 77-92.

SHANNON, C. E. AND WEAVER, W. 1963. The Mathematical Theory of Communication. Univ. Illinois Press, Urbana.

SOULE, M. 1971. The variation problem: the gene-flow variation hypothesis. Taxon, 20,37-50.

THIEBAUT, B. 1979. Etudes des précipitations: diversité dans l'espace géographique et modifications d'une année à l'autre. Bull. Soc. Languedoc. Geogr., 13, 205-224.

TOMEKPE, K., LUMARET R. AND VALDEYRON, G. 1982. Diversité enzymatique et vigueur dans une population naturelle de dactyles tétraploides. Agronomie, 2(2), 107-112.

VALIZADEH, M. AND VALDEYRON, G. 1979. Importance adaptative du polymorphisme enzymatique chez le figuier (Ficus carica L.). Ann. Amélior. Plantes, 29(2), 213-225.

WALTER, H AND LIETH, H., 1967. Klimadiagramm-Weltatlas. Jena, VEB Gustav Fischer Verlag. 